Session 2309

\title{
Integrating Biology and Engineering: What Works and What Doesn't
}

\author{
Susan M. Blanchard \\ North Carolina State University
}

I. Introduction

The database (http://summit.whitaker.org) created for The Biomedical Engineering Educational Summit that was held on December 7-10, 2000 in Lansdowne, VA was used to determine biological science and physiology course requirements for the 21 ABET-accredited Biomedical Engineering (BME) programs listed in Table I. Thirteen of the programs require at least 4 semester hours of biological science with only one program (Johns Hopkins, 580.221: Molecules and Cells) having a course that is taught within the department. Five of the programs (Case Western Reserve, Duke, Louisiana Tech, Rensselaer Polytechnic Institute, and Texas A \& M) do not require any introductory biology course. All but two of the programs (Duke and Marquette) require at least 3 semester hours of physiology or engineering physiology with over half of the programs offering engineering physiology courses. The 20 programs other than Duke, which has biology and physiology as electives, required a total of $9.8 \pm 4.0$ semester hours of biology and physiology.

The Biological and Agricultural Engineering (BAE) Department at NC State developed an engineering biology course in 1995 and an engineering physiology course in 2001. These attempts to integrate engineering into the life sciences are discussed in the following sections.

II. Integrating Engineering with General Biology

The B. S. in Biological Engineering (BE) with concentrations in Agricultural, Biomedical, Bioprocess, and Environmental Engineering was first offered at NC State University in the fall of 1994. A new 4-hr course, BAE 235: Engineering Biology, was developed to help meet ABET requirements for 48 hours of engineering topics and 16 hours of biological science with no more than 8 hours double counted with engineering hours. BAE 235 counted as 4 hours of biological science and 3 hours of engineering topics and covered general biology with engineering applications. This made it possible for the BE curriculum to stay within the legislatively mandated maximum of 128 semester hours while meeting the requirements for ABET accreditation.

BAE 235 had three 1-hr lectures each week that were taught in the BAE Department's classroom space and one 3-hr lab that was taught in the same labs used for general biology. A college biology textbook ${ }^{1}$ was used for the course. The laboratory manual ${ }^{2}$ was the same one that was used for BIO 125: General Biology, which also had three lectures and a 3-hr lab each week. 
Additional books were used by the instructor to provide supplemental engineering and statistics material ${ }^{3-6}$. According to the course description, BAE 235 covered the "Structure, function, and energy transformations of biosystems at the cellular, organismal, and population levels with particular attention to the solutions of engineering problems related to these transformations" while BIO 125 covered "Basic principles and concepts of biology, including the structure and function of cells and organisms, development, heredity, evolution, and ecology." In addition to using engineering examples, BAE 235 also had to provide students with enough biology to make it possible for them to take advanced courses for the two required biological science electives, one 4-hr course and one 3-hr course, e.g. basic human anatomy and physiology, cell biology, genetics, microbiology, space biology, neurolinquistic development and disorders, etc.

BAE 235 worked very well for the first 4 years it was taught. On a scale in which 1 is poor, 3 is adequate, and 5 is excellent, the course rating was $4.2 \pm 0.3$ and the teaching effectiveness was $4.3 \pm 0.2$. Students who took BAE 235 reported that they were well prepared for upper level biological science courses. BAE 235 also fulfilled half of the 8 hours of introductory biology required for admission to medical school.

The average enrollment for BAE 235 was $27 \pm 2$ students for the first 4 years with 21 students enrolled in the $5^{\text {th }}$ year (see Table II). The drop in enrollment for the $5^{\text {th }}$ year was primarily due to a decrease in the number of students following the other three concentrations (Agricultural, Bioprocess, and Environmental Engineering) in the BE program since there were 15 students in BAE 235 in 1998 and 14 in 1999 who were in the Biomedical Engineering concentration.

In 1997, the BE curriculum was modified to include a 3-hr statistics course. Since the curriculum was already at its maximum allowable limit of 128 hours, the hours for the statistics course were "found" by reducing three 4-hr courses, including BAE 235, to 3-hr courses, effective in 1999. In the spring of 1999, BAE 235 had two 1-hr lectures and one 3-hr lab each week. The course rating and teaching effectiveness scores both dropped to 3.4, which indicated the student's dissatisfaction and frustration with BAE 235 as a 3-hr course. The main problem was that, even after some topics, e.g. evolution, were eliminated, there was too much material to cover and too little lecture time. The syllabus, lecture slides, and homework sets (see Table III for example problems) from the spring 1999 offering of BAE 235 can be found at http://www.bae.ncsu.edu/bae/courses/bae235/. An additional problem that was not fully appreciated when the change was made from a 4-hr course to a 3-hr course was the impact on students who needed a 4-hr introductory biology course for medical school. Only 2 students who took the 3-hr version of BAE 235 have applied to medical school, and the consequences for these students are not yet known.

In addition to problems with content, BAE 235 began to have issues with space since the labs were taught in rooms allocated to the biological sciences program. Table II shows that the demand for spring seats in introductory biology courses grew more between 1994 and 1999 $(26.2 \%)$ than overall spring university enrollment $(4.5 \%)$. Increasing the number of students from 608 to 767 meant that 8 lab sections had to be added to an already full schedule. BAE 235 had an average enrollment of $26 \pm 3$, which meant that it had to have two 20 -student lab sections. Thus, BAE 235 occupied space that could have been used to serve 40 students when it actually only served an average of 26 each year. This meant that 70 students were prevented from taking 
BIO 125 over the 5 years that BAE 235 was taught because there were no lab seats available for them. Because a different group owned the lab space, control over when BAE 235 labs could be offered was minimal and provided another source of friction. Using space allocated to the biological sciences program did provide one advantage since it meant that only a limited amount of equipment and supplies had to be purchased in order to teach BAE 235.

Introduction of ABET's EC2000 made it possible for the BAE Department to set its own goals for the program and to consider moving away from a strict adherence to 16 hours of biological science with 8 hours being double counted. The Biomedical Engineering concentration in the $\mathrm{BE}$ degree program was revised for the fall of 2000 to include the 4-hr BIO 125 course rather than the 3-hr BAE 235. A 4-hr biological science elective was dropped from the revised curriculum and the choice of either a 3-hr biological science or a 3-hr engineering science elective was changed to a requirement for a 3-hr engineering science elective. The revised concentration totaled 128 hours and contained 14-16 hours of biological science, depending upon the engineering electives that were selected, with 7 hours of biological science that were not double counted with engineering topics.

One of the factors that influenced the decision to move from BAE 235 to BIO 125, in addition to the drop in student satisfaction with the 3 -hr course and the problems with space allocation for the lab, was the difficulty encountered with introducing engineering content into BAE 235 . Students who were on track within the BE degree program had completed 8 hours of physics, 8 hours of inorganic chemistry, 12 hours of calculus, 3 hours of introduction to biological engineering and computing, and 4 hours of statics when they took BAE 235. Thus, even if they were on schedule, which many of them were not, they had only completed 7 hours of engineering courses and had very little engineering knowledge that could be used as background for the topics covered in BAE 235.

Another factor that was influential was an increase in the number of students who had credit for BIO 125 before they matriculated in the BE degree program. These students were allowed to count their biology credit for BAE 235 if they took an additional 3-hr engineering course. During 1998 and 1999, between 22\% and 25\% of the juniors who enrolled in BAE 465: Biomedical Engineering Applications, the first course specifically for Biomedical Engineering concentration students, had not taken BAE 235 because they had received credit for general biology.

Based on the data in Table I, the decision to drop BAE 235 and to have students take general biology appears to be in line with what most ABET-accredited BME programs require.

Dropping BAE 235 also freed up the faculty resources that were needed to develop and teach the junior-level course in engineering physiology that is described in the following section. The main disadvantage for our students is that they are now forced to learn biology in a large lecture section (average size of 126 in spring 2000) rather than in a small, interactive class. Another disadvantage is that they now take only one departmental course in the spring of their sophomore year instead of two. The main advantage for students who do not have prior credit for general biology is that they have more than one lecture section and multiple lab sections to choose from so it should make it easier for them to develop course schedules. 


\section{Integrating Engineering with Physiology}

The proposed B. S. in Biomedical Engineering, which should go into effect in the fall of 2001 and will be accredited under the Bioengineering criteria, has the same requirement for 7 hours of biological science courses as the Biomedical Engineering concentration in the BE degree program. BAE 381: Human Physiology for Engineers, which has 3 hours of biological science and 2 hours of engineering science, is a new course that is required for the BME degree program. Having a course that contains both engineering and physiology increased the amount of biological science in the curriculum to 16 hours with 8 hours not double counted with engineering credits and helped meet ABET's EC2000 criteria for Bioengineering, which states that students should have "an understanding of biology and physiology."

Getting permission to develop BAE 381 ran into problems with the Zoology Department whose members were reluctant to endorse a physiology course that was taught outside of their department. The Zoology Department teaches a 4-hr human anatomy and physiology course (ZO 212) that could not be added to the BME curriculum because it would put the total number of hours over the 128-hr maximum. In addition, ZO 212 is only taught during the summers, which would cause scheduling problems for students. The Zoology Department also teaches ZO 421: Principles of Physiology, a 3-hr course that requires the second semester of organic chemistry ( $\mathrm{CH} 223)$, which is not required for the BME curriculum, and ZO 250: Animal Anatomy and Physiology, a 4-hr course that has an additional 4-hr course, ZO 150: Animal Diversity, as a prerequisite. Thus, the alternative 3-hr physiology course has too many prerequisites, which the Zoology Department was unwilling to waive for BME students, for it to fit within the 128-hr curriculum. Since they could not provide an appropriate alternative, the Zoology Department reluctantly endorsed the development of BAE 381.

The overlap between ZO 421 and BAE 381 is restricted to the basics of physiology. The course description for ZO 421 states that the course provides "a comprehensive survey of the processes involved in the function of specialized cells, tissues and organ systems with emphasis on basic concepts with orientation toward mammalian and human systems" while the course description for BAE 381 states that this course provides "a quantitative approach to human physiology from the biomedical engineering perspective with emphasis on measurement methods and mathematical modeling of cellular physiology, membrane dynamics, feedback and control, and selected organ systems with computer-based laboratory exercises and homework."

BAE 381 has two required textbooks, one from human physiology ${ }^{7}$ and one from biomedical engineering ${ }^{8}$. Additional resource books will provide examples from mathematical physiology ${ }^{9}$ and with MATLAB $®$ and SIMULINK $®$ (The Mathworks, Natick, MA) for systems analysis and simulations ${ }^{10-12}$. The course description and syllabus are available at http://www.bae.ncsu.edu/bae/courses/bae381. What will work and what won't during the first offering of BAE 381 are still unknown, but the existence of engineering physiology courses in 11 ABET-accredited BME programs suggests that the course should provide a useful approach for integrating engineering and biology. 
Table I: Hours of Biology and Physiology in ABET Accredited BME Programs

\begin{tabular}{|c|c|c|c|c|}
\hline $\begin{array}{l}\text { ABET accredited programs } \\
\text { (Bioengineering criteria) }\end{array}$ & $\begin{array}{c}\text { Total } \\
\text { Semester } \\
\text { (hrs) }\end{array}$ & $\begin{array}{c}\text { General, } \\
\text { Cellular, or } \\
\text { Molecular } \\
\text { Biology (hrs) }\end{array}$ & $\begin{array}{l}\text { Physiology } \\
\text { (hrs) }\end{array}$ & $\begin{array}{l}\text { Engineering } \\
\text { Physiology } \\
\text { (hrs) }\end{array}$ \\
\hline Arizona State University & 128 & 4 & & 4 \\
\hline Boston University & 136 & 4 & 4 & \\
\hline $\begin{array}{l}\text { Case Western Reserve } \\
\text { University }\end{array}$ & 129 & & & 6 \\
\hline Catholic University of America & 128 & 4 & 4 & \\
\hline Duke University & 113 & $3-4^{*}$ & $4 *$ & \\
\hline Johns Hopkins University & 124.5 & $4 * *$ & & 6 \\
\hline Louisiana Tech University & 128 & & 7 & \\
\hline Marquette University & 133 & 9 & & $3 *$ \\
\hline $\begin{array}{l}\text { Milwaukee School of } \\
\text { Engineering }\end{array}$ & $\begin{array}{l}210 \\
(\mathrm{qtr})\end{array}$ & 4 & 8 & \\
\hline Northwestern University & $\begin{array}{l}192 \\
(\mathrm{qtr})\end{array}$ & 4 & & 8 \\
\hline Rensselaer Polytechnic Institute & 127 & & 4 & 4 \\
\hline Syracuse University & 132 & 4 & & 8 \\
\hline Texas A \& M & 135 & & & 8 \\
\hline Tulane University & 129 & 4 & & 8 \\
\hline $\begin{array}{l}\text { University of California, San } \\
\text { Diego }\end{array}$ & $\begin{array}{l}192 \\
(\mathrm{qtr})\end{array}$ & 24 & 12 & \\
\hline University of Illinois, Chicago & 128 & 5 & 8 & \\
\hline University of Iowa & 128 & 4 & 4 & \\
\hline University of Miami & 134 & 5 & 3 & \\
\hline University of Pennsylvania & 125 & 4.5 & & 3 \\
\hline Vanderbilt University & 128 & 8 & & 6 \\
\hline Wright State University & $\begin{array}{l}202 \\
(\mathrm{qtr})\end{array}$ & 4 & 9 & \\
\hline
\end{tabular}

*Elective

**Taught in BME Department 
Table II: NC State Enrollment History

\begin{tabular}{|c|c|c|c|c|}
\hline Year & $\begin{array}{c}\text { Total spring } \\
\text { undergraduate } \\
\text { enrollment }\end{array}$ & $\begin{array}{c}\text { All spring } \\
\text { biological } \\
\text { science courses }\end{array}$ & BAE 235 & $\begin{array}{c}\text { Percent total } \\
\text { students in all } \\
\text { biology courses }\end{array}$ \\
\hline 1994 & 17,199 & 608 & - & 3.5 \\
\hline 1995 & 17,343 & 590 & 28 & 3.6 \\
\hline 1996 & 17,301 & 674 & 25 & 4.0 \\
\hline 1997 & 17,443 & 688 & 27 & 4.1 \\
\hline 1998 & 17,977 & 769 & 29 & 4.4 \\
\hline 1999 & 17,974 & 767 & 21 & 4.4 \\
\hline 2000 & 18,032 & 780 & - & 4.3 \\
\hline
\end{tabular}

Table III: Sample Homework Problems for BAE 235

\begin{tabular}{|c|}
\hline $\begin{array}{l}\text { Find one newspaper, scientific journal, or magazine article that focuses on an engineering } \\
\text { application that uses organisms from the Kingdom of Monera and was published in 1998. (a) } \\
\text { Turn in a copy of the first page of each article. Write the title and source (volume, date, page) on } \\
\text { the first page if they do not appear there. (b) Write a one-page summary of the article which } \\
\text { identifies its biological and engineering relevance. }\end{array}$ \\
\hline $\begin{array}{l}\text { The sphere, rod, and rectangular parallelepiped represent common shapes for different living } \\
\text { cells. Assume that you have } 3 \text { cells: a sphere, a rod (modeled as a cylinder), and a rectangular } \\
\text { parallelepiped. Assume that the volume of each of the cells is } 1 \mathrm{ml}\left(1 \mathrm{ml}=1 \mathrm{~cm}^{3}\right) \text {, that the } \\
\text { diameter of the sphere and the rod are equal, and each of two sides of the rectangular cell equals } \\
\text { the radius of the sphere. What are the surface/volume ratios for these shapes? Show your } \\
\text { calculations. Why might a given weight of small cells be more metabolically active than the } \\
\text { same weight of large cells? }\end{array}$ \\
\hline $\begin{array}{l}\text { Briefly describe how wine (yogurt, cheese, or beer) is made. What biological and engineering } \\
\text { issues are important in large-scale commercial operations that make wine (yogurt, cheese, or } \\
\text { beer)? }\end{array}$ \\
\hline $\begin{array}{l}\text { Assume that the maximum tolerable temperature rise for a dividing cell is } 10 \text {-deg C. (a) Assume } \\
\text { that the } E \text {. coli bacterium in Figure } 3.20 \text { (p. } 60) \text { is spherical in shape and has a diameter of } 1 \\
\text { micrometer. How quickly could it divide? (b) Assume that the same } E \text {. coli cell spends three } \\
\text { times as much time growing between divisions as it does dividing. How much time would it take } \\
\text { for a single bacterium to result in approximately a million offspring? }\end{array}$ \\
\hline $\begin{array}{l}\text { Assume that the maximum tolerable temperature rise for a dividing cell is 10-deg C. Calculate } \\
\text { the minimum division time for cells with radii of } 0.005 \mathrm{~cm}, 0.5 \mathrm{~cm} \text {, and } 5 \mathrm{~cm} \text {. Express your } \\
\text { results in } \mathrm{s} \text {, min, or days, depending upon what is appropriate. }\end{array}$ \\
\hline
\end{tabular}


Bibliography

1. Starr, C. Biology - concepts and applications. $3^{\text {rd }}$ ed. Belmont, CA: Wadsworth Publishing Company (1997).

2. Niedzlek-Feaver, M., Zimmerman, J. W., \& Lytle, C. F. Laboratory Investigations in Biology. $3^{\text {rd }}$ ed. Raleigh, NC: North Carolina State University (1997).

3. Pennycuick, C. J. Newton Rules Biology - A physical approach to biological problems. Oxford, UK: Oxford University Press (1992).

4. Harte, J. Consider a Spherical Cow - A Course in Environmental Problem Solving. Mill Valley, CA: University Science Books (1988)

5. Morowitz, H. J. Energy Flow in Biology. Woodbridge, CT: Ox Bow Press (1979).

6. Samuels, M. L. Statistics for the Life Sciences. San Francisco, CA: Dellen Publishing Company (1989).

7. Silverthorn, D. U. Human Physiology - An Integrated Approach, 2nd Ed. Upper Saddle River, NJ: Prentice Hall (2001).

8. Enderle, J. D., Blanchard, S. M., \& Bronzino, J. B. Introduction to Biomedical Engineering. San Diego, CA: Academic Press (2000).

9. Keener J. \& Sneyd J. Mathematical Biology. New York, NY: Springer-Verlag (1998).

10. Khoo, M. C. K. Physiological Control Systems - Analysis, Simulation, and Estimation. New York, NY: Institute of Electrical and Electronics Engineers, Inc. (2000).

11. Wilson, H. R. Spikes, Decisions, and Actions: The Dynamical Foundations of Neurosciences. Oxford University Press (1999).

12. Phillips, C. A. Human Factors Engineering. Somerset, NJ: John Wiley \& Sons, Inc. (2000).

\section{SUSAN M. BLANCHARD}

Susan M. Blanchard received the A.B. in Biology from Oberlin College in 1968 and the M.S. and Ph.D. degrees in Biomedical Engineering from Duke University in 1980 and 1982, respectively. She worked for a year as Member of Technical Staff for Rockwell International before joining the Department of Surgery's Cardiac Electrophysiology Lab at Duke University Medical Center in 1983. In 1990, she became an Assistant Research Professor in the Department of Biomedical Engineering at Duke University and the Executive Officer of the Engineering in Medicine and Biology Society (EMBS) of the Institute of Electrical and Electronics Engineers (IEEE). In 1993, she joined the Department of Biological and Agricultural Engineering at North Carolina State University as an Associate Professor. She was President of the IEEE EMBS in 1996 and received the society's Service Award in 1998. She is a Senior Member of the Biomedical Engineering Society and of the IEEE. She became a Fellow of the American Institute for Medical and Biological Engineering (AIMBE) in 1997 was a member of the AIMBE Board in 19982000. She has co-authored Introduction to Biomedical Engineering (Academic Press, 2000) with John D. Enderle and Joseph D. Bronzino.

Proceedings of the 2001 American Society for Engineering Education Annual Conference \& Exposition Copyright $@ 2001$, American Society for Engineering Education 